\title{
IMPLEMENTASI MODEL PEMBELAJARAN TEAM ASSISTED INDIVIDUALIZATION (TAI) UNTUK MENINGKATKAN AKTIFITAS DAN HASIL BELAJAR MATERI POKOK PASTA
}

\author{
Luh Sari \\ SMK N 2 Singaraja \\ E-mail : luh.sari8@gmail.com
}

\begin{abstract}
ABSTRAK
Tujuan dari diadakannya penelitian ini adalah untuk meningkatkan aktivitas dan hasil belajar siswa kelas XIA5 di SMK N 2 Singaraja Tahun Pelajaran 2016/2017 pada materi pelajaran menganalisis, mengolah dan menyajikan hidangan pasta dengan menerapkan model pembelajaran Kooperatif Tipe Team Assisted Individualization (TAI). Penelitian ini adalah penelitian tindakan kelas (PTK). Subjek penelitian ini adalah siswa kelas XI A5 di SMK Negeri 2 Singaraja tahun pelajaran 2016/2017 dengan jumlah siswa sebanyak 39 orang ( 18 ) orang siswa perempuan dan ( 21 ) orang siswa laki-laki ). Sedangkan objek penelitian ini adalah aktivitas dan hasil belajar siswa setelah diterapkannya model pembelajaran TAI. Data aktivitas belajar siswa dikumpulkan dengan menggunakan lembar observasi aktivitas belajar siswa yang telah dipersiapkan, sedangkan data hasil belajar siswa yaitu menggunakan tes esay. Analisis data yang digunakan pada penelitian ini menggunakan analisis data deskriptif. Berdasarkan analisis data yang dilakukan dapat disimpulkan bahwa implementasi model kooperatif tipe TAI dapat meningkatkan aktivitas dan hasil belajar siswa pada mata pelajaran Pengolahan dan Penyajian Makanan Kontinental kelas XI A5 SMK Negeri 2 Singaraja Tahun Pelajaran 2016/2017.
\end{abstract}

Kata kunci: model pembelajaran TAI, aktivitas belajar, hasil belajar siswa

\begin{abstract}
The purpose of this research was to improve learning activities and learning outcomes of XIA5 class students at Singaraja N 2 Vocational High School 2016/2017 in the subject matter of analyzing, processing and serving pasta dishes by applying the Team Assisted Individualization (TAI) Cooperative Learning model. This research is classroom action research. The subjects of this study were class XI A5 students at SMK Negeri 2 Singaraja 2016/2017 academic year with a total of 39 students (18) female students and (21) male students). While the object of this research is the activity and student learning outcomes after the application of the TAI learning model. Student learning activity data is collected using observation sheets of student learning activities that have been prepared, while the student learning outcomes data is using the Esay test. Data analysis used in this study used descriptive data analysis. Based on the data analysis conducted, it can be concluded that the implementation of the TAI type cooperative model can improve student learning activities and outcomes on the subject of Continental Food Processing and Presentation class XI A5 Singaraja State Vocational High School 2, 2016/2017.
\end{abstract}

Keywords: TAI learning model, learning activities, student learning outcomes 


\section{PENDAHULUAN}

Belajar adalah proses atau usaha yang dilakukan setiap individu untuk memperoleh suatu perubahan tingkah laku baik dalam bentuk pengetahuan, keterampilan maupun sikap dan nilai yang positif sebagai pengalaman untuk mendapatkan sejumlah kesan dari bahan yang telah dipelajari. Kegiatan belajar tersebut ada yang dilakukan di sekolah, di rumah, dan di tempat lain seperti di museum, di laboratorium, dan di hutan. Proses belajar ini memerlukan waktu yang cukup lama dan tidak bisa instan untuk memahami materi yang dipelajari.

Proses belajar berhubungan erat dengan pengertian belajar dan mengajar. Belajar, mengajar dan pembelajaran terjadi bersamasama untuk menumbuhkan motivasi siswa. Belajar dapat terjadi tanpa guru atau tanpa kegiatan mengajar dan pembelajaran formal lain. Sedangkan mengajar meliputi segala hal yang guru lakukan di dalam kelas. (Duffy dan Roehler:2007) Mengatakan apa yang dilakukan guru agar proses belajar mengajar berjalan lancar, bermoral dan membuat siswa merasa nyaman merupakan bagian dari aktivitas mengajar, juga secara khusus mencoba dan berusaha untuk mengimplementasikan kurikulum dalam kelas.

Sementara itu pembelajaran adalah suatu usaha yang sengaja melibatkan dan menggunakan pengetahuan profesional yang dimiliki guru untuk mencapai tujuan kurikulum.

Kurikulum 2013 siswa dituntut untuk lebih aktif dalam proses pembelajaran. Proses pemahaman siswa terhadap materi kadang kala menjadi kendala yang sangat signifikan bagi siswa dalam proses belajar. Hal ini disebabkan oleh beberapa aspek baik yang berasal dari dalam diri siswa (kemauan dan kemampuan) maupun dari luar diri siswa (lingkungan, dan teman). Untuk menumbuhkan kemampuan dan kemauan belajar dari siswa perlu adanya dorongan atau motivasi sehingga siswa bisa belajar lebih aktif dan bisa memahami apa yang dipelajari.

Pencapaian terhadap motivasi memang bukanlah hal yang mudah untuk diwujudkan karena motivasi memiliki 2 jenis berdasarkan asalnya. Selain itu juga perlu dipertajam mengenai seberapa besar pengaruh motivasi terhadap pembelajaran siswa dikelas maupun diluar kelas saat menerima pembelajaran dan penerapannya. Siswa memainkan peran penting untuk mempersiapkan dirinya menjadi aktor yang mampu menampilkan keunggulan dirinya sebagai sosok yang tangguh, percaya diri, kreatif, mandiri, dan profesional pada bidangnya masing-masing. Untuk itu diperlukan adanya perpaduan antara kesiapan siswa dalam belajar dengan metode yang digunakan oleh guru dalam mengajar. Guru diharapkan memiliki kemampuan menerapkan metode pembelajaran dengan baik sehingga dapat melakukan pembelajaran yang lebih efektif.

Ada beberapa teknik untuk memproleh data informasi mengenai proses belajar mengajar yaitu Respon siswa melalui kuesioner dimana penilaian proses belajar mengajar melalui kuesioner ini cara yang paling baik dilakukan kepada siswa setelah proses belajar mengajar yang dilaksanakan yaitu melalui pendapat tentang kegiatan pembelajaran dikelas secara berlangsung, kemudian siswa diminta pendapatnya mengenai proses belajar mengajar yang baru saja ditempuhnya dengan model pembelajaran yang baru, misalnya ia diminta pendapat tentang cara mengajar guru dengan menerapkan model pembelajaran yang lain daripada yang sudah diterapkan dari guru sebelumnya, setelah itu guru bisa mengetahui kekurangan dan kelebihan sebagai perbaikan dan penyempurnaan mengajar selanjutnya.

Proses belajar mengajar yang berlangsung di SMK kejuruan diharapkan dapat memfasilitasi siswa untuk mencapai kompetensi yang ditargetkan oleh kurikulum. Standar proses pendidikan memiliki peranan yang sangat penting dalam upaya meningkatkan kualitas pendidikan. Guru juga merupakan komponen yang sangat penting dalam meningkatkan mutu pendidikan, agar dalam penyampaian materi sesuai dengan panduan silabus dan rancangan program pengajaran, untuk itu diperlukan inovasi- 
inovasi baru yang disesuaikan dengan karakteristik siswa, sehingga siswa mampu mencapai KKM yang diharapkan oleh sekolah.

Sekolah Menengah Kejuruan Negeri 2 Singaraja ini merupakan sekolah pariwisata yang memiliki 5 program bidang keahlian, salah satunya yaitu program keahlian Tata Boga. Program pendidikan yang diberikan di sekolah tersebut dibedakan menjadi tiga bagian yaitu pendidikan normatif (60\%), adaptif (20\%), dan produktif (20\%). pengolahan makanan kontinental merupakan pembelajaran program pendidikan produktif yang menanamkan dan mengembangkan pengetahuan ketrampilan dan sikap pada saat siswa melaksanakan kegiatan belajar. Oleh sebab itu, dalam pembelajaran pengolahan dan penyajian makanan kontinental, guru hendaknya menyadari bahwa tujuan pembelajaran materi pokok hidangan dari pasta bukan hanya menyediakan peluang kepada siswa untuk belajar fakta-fakta dan teori-teori saja, tetapi juga untuk mengembangkan kebiasaan dan sikap ilmiah siswa.

Berdasarkan hasil observasi awal dan wawancara dengan beberapa siswa di SMK N 2 Singaraja pada tanggal 5 oktober 2016 diketahui hasil belajar belum mencapai standar yang diharapkan, dimana siswa kelas XIA5 tahun ajaran 2016/2017 belum mencapai nilai KKM yang ditetapkan pada semester ganjil yaitu 80. Strategi yang sudah diterapkan yaitu seperti tanya jawab dan ceramah serta Siswa cenderung kurang antusias dalam mengikuti pelajaran padahal fasilitas sekolah sangat mendukung proses pembelajaran. Selain itu model pembelajaran yang diterapkan masih bersifat konvensional, di mana pembelajaran di kelas masih berpusat pada guru.

Berdasarkan hasil wawancara dengan beberapa siswa kelas XIA5 diperoleh beberapa permasalahan penyebab rendahnya hasil belajar siswa kelas XIA5 yaitu: pertama, pembelajaran di kelas masih terpusat pada guru sehingga siswa tidak memiliki inisiatif untuk menggali informasi lebih lanjut. Kedua, siswa kurang aktif dalam pembelajaran. Hal ini terlihat dari tanya jawab yang dilakukan guru selama proses pembelajaran. Tidak semua siswa memberikan respon terhadap pertanyaan yang disampaikan guru, dan hanya beberapa orang siswa saja yang mau menanggapi. Siswa yang kurang aktif dalam pembelajaran menyebabkan guru kesulitan mengetahui penguasaan siswa terhadap materi, apakah konsep yang dimiliki siswa sudah benar atau masih menyimpang. Ketiga, dalam pengerjaan tugas hanya siswa yang pandai saja mau mengerjakan tugas dengan baik, sedangkan siswa yang memiliki kemampuan kurang tidak antusias dalam mengerjakan tugas. Keempat, siswa jarang menyampaikan kesimpulan dari materi yang disampaikan pada akhir pembelajaran. Penyampaian kesimpulan ini sangat penting karena dengan ini siswa akan mampu menangkap inti dari pembelajaran. Apabila siswa tidak mampu menyampaikan kesimpulan, ini berarti siswa belum menangkap inti pembelajaran yang disampaikan guru.

Upaya yang dilakukan untuk memperbaiki hasil belajar pelajaran pengolahan makanan kontinental dapat dilakukan dengan mengadakan perbaikan dalam kegiatan pembelajaran, yaitu dengan menarapkan model pembelajaran yang mampu meningkatkan keantusiasan siswa terhadap pembelajaran menganalisis dan membuat dan menyajikan hidangan dari pasta, membuat siswa lebih aktif dalam pembelajaran, mengarahkan siswa menarik kesimpulan dari pelajaran yang diberikan, sehingga proses pembelajaran menjadi lebih bermakna dan siswa dapat menangkap inti dari pembelajaran. Selain itu terdapat pula solusi alternatif untuk permasalahan tersebut, yaitu dengan menggunakan model pembelajaran Kooperatif tipe Team Assisted Individualization (TAI). TAI merupakan salah satu tipe pembelajaran Cooperative Learning yang dipadukan dengan pembelajaran individual. Penggunaan model TAI bertujuan supaya siswa lebih termotivasi untuk belajar pelajaran pengolahan dan penyajian makanan kontinental, sehingga siswa akan lebih paham akan materi yang diberikan oleh guru, karena siswa ikut terlibat dalam proses belajar mengajar. Slavin (dalam Ariani,1995) 
menyatakan bahwa belajar kooperatif model TAI mempunyai keunggulan seperti: (1) Meningkatkan hasil belajar, (2) Meningkatkan motivasi belajar pada diri siswa, (3) Mengurangi perilaku yang mengganggu, (4) Program ini akan sangat membantu siswa yang lemah.

Penerapan model pembelajaran TAI akan memberikan dua keuntungan sekaligus, yaitu keuntungan dari pembelajaran kooperatif dan keuntungan dari pembelajaran secara individual. Tipe pembelajaran kooperatif dapat meningkatkan interaksi antar siswa serta hubungan yang saling menguntungkan antar mereka. Siswa dalam kelompok akan belajar mendengar ide atau gagasan orang lain, berdiskusi, menawarkan, atau menerima kritikan yang membangun, dan siswa tidak merasa terbebani ketika ternyata pekerjaannya salah. Sementara itu, pengajaran secara individual mendidik siswa untuk belajar secara mandiri, tidak menerima pelajaran secara mentah dari guru. Dengan pengajaran seperti ini, siswa dapat mengeksplorasi pengetahuan dan pengalamannya sendiri dalam mempelajari suatu bahan ajar, sehingga yang terjadi pemahaman siswa terhadap materi tersebut semakin terarah, bukan semata-mata hafalan yang didapatkannya dari guru .

Berdasarkan uraian tersebut, maka peneliti tertarik untuk melaksanakan penelitian tindakan kelas melalui model pembelajaran Kooperatif Tipe Team Assisted Individualization (TAI) untuk meningkatkan hasil belajar pengolahan makanan kontinental Siswa Kelas XIA5 di SMK N 2 Singaraja.

\section{METODE PENELITIAN}

Penelitian ini dilaksanakan pada siswa XIA5 bertempat di SMK Negeri 2 Singaraja dalam pembelajaran pengolahan dan penyajian makanan kontinental. Penelitian akan dilaksanakan pada semester ganjil tahun ajaran 2016/2017.

Subjek penelitian ini adalah siswa kelas XI A5 di SMK Negeri 2 Singaraja tahun pelajaran 2016/2017 dengan jumlah siswa sebanyak 39 orang ( 18 ) orang siswa perempuan dan ( 21 ) orang siswa laki-laki ).
Alasan peneliti menggunakan siswa kelas XIA5 sebagai subjek penelitian karena di kelas tersebut ditemukan permasalahanpermasalahan yang telah dikemukakan pada latar belakang. Sedangkan objek penelitian ini adalah aktivitas dan hasil belajar siswa setelah diterapkannya model pembelajaran TAI.

$\begin{array}{rll}\text { Upaya } & \text { yang } & \text { dilakukan untuk } \\ \text { memperbaiki } & \text { hasil belajar pelajaran }\end{array}$ pengolahan makanan kontinental dapat dilakukan dengan mengadakan perbaikan dalam kegiatan pembelajaran, yaitu dengan menarapkan model pembelajaran yang mampu meningkatkan keantusiasan siswa terhadap pembelajaran menganalisis dan membuat dan menyajikan hidangan dari pasta, membuat siswa lebih aktif dalam pembelajaran, mengarahkan siswa menarik kesimpulan dari pelajaran yang diberikan, sehingga proses pembelajaran menjadi lebih bermakna dan siswa dapat menangkap inti dari pembelajaran. Selain itu terdapat pula solusi alternatif untuk permasalahan tersebut, yaitu dengan menggunakan model pembelajaran Kooperatif tipe Team Assisted Individualization (TAI). TAI merupakan salah satu tipe pembelajaran Cooperative Learning yang dipadukan dengan pembelajaran individual. Penggunaan model TAI bertujuan supaya siswa lebih termotivasi untuk belajar pelajaran pengolahan dan penyajian makanan kontinental, sehingga siswa akan lebih paham akan materi yang diberikan oleh guru, karena siswa ikut terlibat dalam proses belajar mengajar. Slavin (dalam Ariani,1995) menyatakan bahwa belajar kooperatif model TAI mempunyai keunggulan seperti: Meningkatkan hasil belajar, (2) Meningkatkan motivasi belajar pada diri siswa, (3) Mengurangi perilaku yang mengganggu, (4) Program ini akan sangat membantu siswa yang lemah.

Penerapan model pembelajaran TAI akan memberikan dua keuntungan sekaligus, yaitu keuntungan dari pembelajaran kooperatif dan keuntungan dari pembelajaran secara individual. Tipe pembelajaran kooperatif dapat meningkatkan interaksi antar siswa serta hubungan yang saling menguntungkan antar mereka. 
Dalam Penelitian ini akan dikembangkan perangkat pembelajaran meliputi rencana pembelajaran dan tes hasil belajar. Semua perangkat pembelajaran disusun disesuaikan dengan jenis pendekatan yang diterapkan untuk meningkatkan kualitas proses dan hasil belajar siswa. Dalam penelitian ini akan direncanakan dalam 2 siklus dimana masing masing siklus terdiri dari empat tahap yaitu : (1) perencanaan tindakan, (2) pelaksanaan tindakan, (3) observasi/evaluasi, (4) refleksi.

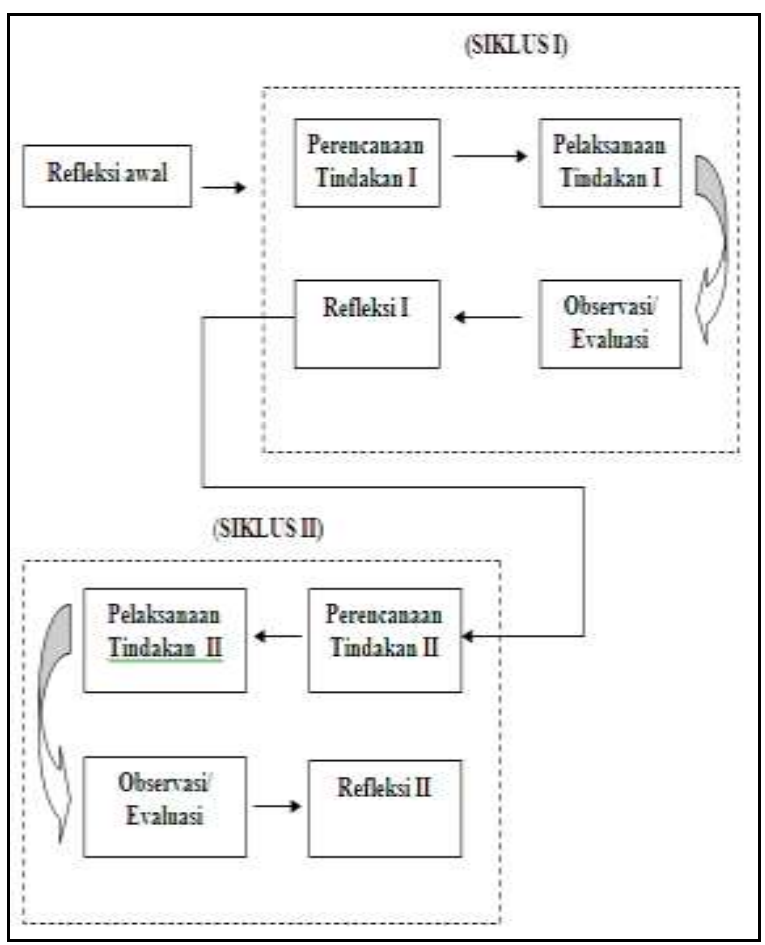

Gambar 1. Siklus PTK

Observasi dilakukan oleh peneliti
selama proses pembelajaran dengan penerapan model TAI untuk meningkatkan aktivitas belajar siswa materi danish pastry. Observasi dilakukan dengan menggunakan lembar observasi aktivitas belajar siswa yang telah dipersiapkan. Data-data yang dikumpulkan dalam penelitian ini adalah nilai hasil belajar siswa yang meliputi nilai aspek kognitif, aspek afektif, dan aspek psikomotor serta respon siswa terhadap penerapan model pembelajaran TAI dalam pembelajaran pengolahan dan penyajian pasta.

Setelah data aktivitas belajar dan hasil belajar siswa terkumpul, selanjutnya dilakukan analisis data dengan menggunakan analisis deskriptif.

\section{HASIL DAN PEMBAHASAN Hasil Penelitian}

Sebelum melaksanakan kegiatan pembelajaran siklus I, peneliti terlebih dahulu melakukan sosialisasi tentang model pembelajaran kooperatif tipe TAI berbantuan LKS, setelah itu penerapan model pembelajaran kooperatif tipe TAI ini diterapkan dalam pembelajaran pasta melalui pelaksanaan siklus I dan dilanjutkan ke siklus II.

Perkembangan aktivitas belajar siswa pertemuan siklus I dengan kualifikasi cukup aktif dengan rata-rata pada akhir siklusya sebesar 10,28 dengan kualifikasi cukup aktif, sehingga aktivitas belajar siswa dalam siklus I belum memenuhi kualifikasi keberhasilan yaitu kualifikasi aktif.

Analisis data hasil belajar pada siklus I menunjukkan bahwa tes hasil belajar siswa rata-rata 79,67 dengan Ketuntasan Klasikal (KK) sebesar $66.66 \%$. Banyaknya siswa yang tuntas memenuhi KKM yaitu sebanyak 26 orang dan siswa yang belum memenuhi KKM sebanyak 13 orang.

Untuk pencapaian nilai hasil belajar, masih ada beberapa siswa yang tidak memenuhi KKM. Hal ini dipengaruhi kebiasaan siswa yang kurang aktif dalam mengikuti pembelajaran sehingga perlu adanya penekanan terhadap penilaian hasil belajar yang diterapkan dalam pelaksanaan tindakan. Berdasarkan hasil refleksi maka perlu adanya perbaikan penerapan model pembelajaran kooperatif tipe TAI pada siklus II untuk memperoleh hasil yang lebih optimal. Pelaksanaan siklus II diadakan upaya-upaya perbaikan sesuai dengan kekurangankekurangan yang dialami selama pelaksanaan siklus I.

Pada siklus II nilai aktivitas belajar siswa meningkat tiap pertemuan. Kualifikasi untuk siklus II mencapai kualifikasi sangat aktif dengan presentase $84.62 \%$. Berdasarkan kualifikasi keberhasilan penelitian, ini dikatakan berhasil apabila aktivitas belajar siswa mencapai kualifikasi aktif. Sehingga 
pelaksanaan pada tindakan siklus II sudah berhasil dilihat dari segi aktivitas belajar siswa. Pada hasil belajar siswa, rata-rata respon siswa terhadap penerapan pembelajaran sebesar 80.29 yaitu dengan kualifikasi sangat positif, sehingga dapat disimpulkan bahwa respon siswa terhadap penerapan model pembelajaran kooperatif tipe TAI direspon positif oleh seluruh siswa.

Skor hasil belajar siswa menunjukkan bahwa penerapan model kooperatif tipe TAI pada pembelajaran pengolahan dan penyajian makanan kontinental berbantuan LKS di kelas XIA5 dapat meningkatkan aktivitas belajar siswa yaitu dari rata-rata 10.28 siklus I menjadi 14.77 pada siklus II serta hasil belajar siswa yaitu dari rata-rata 79.67 siklus I menjadi 85.76 pada siklus II.

Perbandingan rata-rata skor aktivitas siswa siklus I dan siklus II dapat dilihat pada Tabel 1 sebagai berikut:

Tabel 1. Perbandingan Rata-rata Skor Aktivitas Siswa Siklus I dan Siklus II

\begin{tabular}{lll}
\hline \multirow{2}{*}{ Keterangan } & Siklus & \\
\cline { 2 - 3 } & I & II \\
\hline Rata-rata Skor Siswa & 10,28 & 14.77 \\
Kualifikasi & Cukup Aktif & Sangat aktif \\
\hline
\end{tabular}

Perbandingan rata-rata skor hasil belajar siswa siklus I dan siklus II ditunjukkan pada Tabel 2 sebagai berikut:

Tabel 2. Perbandingan Rata-rata Skor Hasil Belajar Siswa Siklus I dan II

\begin{tabular}{llc}
\hline Keterangan & Siklus & \\
\cline { 2 - 3 } & I & II \\
\hline Rata-rata Skor Siswa & 79.67 & 85.76 \\
Ketuntasan Klasikal & $66.66 \%$ & $92.31 \%$ \\
Kualifikasi & Lulus Cukup & Lulus Baik \\
\hline
\end{tabular}

\section{Pembahasan Hasil Penelitian}

Berdasarkan analisis rata-rata aktivitas siswa dan hasil belajar pada siklus I, yaitu adanya peningkatan nilai hasil belajar pada tiap pertemuan, tetapi ada beberapa siswa yang masih belum memenuhi Kriteria Ketuntasan Minimal (KKM) mengacu pada kriteria penilaian yang berlaku di SMK N 2 Singaraja dalam Pembelajaran pengolahan dan penyajian makanan kontinental materi pokok pasta dan belum tercapai ketuntasan klasikal sesuai dengan kriteria keberhasilan yang di tetapkan pada siklus I. Nilai rata-rata aktivitas siswa pada siklus I diperoleh 10.28 kualifikasi cukup aktif dan dengan jumlah siswa yang tidak aktif sebanyak 0 orang siswa yang mendapakan kualifikasi kurang aktif 3 orang, kualifikasi cukup aktif 24 orang, kualifikasi aktif 8 orang, kualifikasi sangat aktif 4 orang. Sedangkan untuk data hasil belajar siklus I adalah 79.67 yaitu 26 siswa yang tuntas dan siswa yang belum memenuhi KKM atau belum tuntas sebanyak 13 orang, sehingga ketuntasan klasikal yang dicapai 66.66\% dengan kualifikasi ketuntasan klasikal belum tuntas atau tidak memenuhi KKM. Dari kualifikasi tersebut, pelaksanaan tindakan siklus I belum mencapai kualifikasi keberhasilan karena ketuntasan klasikal belum berhasil.

Kendala-kendala yang didapatkan kemudian didiskusikan oleh peneliti dan teman sejawat dalam kegiatan refleksi untuk dicarikan solusinya. Melalui kegiatan refleksi ini, disepakati beberapa solusi yang akan dilaksanakan untuk mengatasi kendalakendala dalam pembelajaran.

Model pembelajaran Kooperatif tipe TAI adalah model pembelajaran yang bertujuan mengaktifkan dan semangat siswa 
dalam belajar, menemukan sesuatu berdasarkan pengalamannya sendiri, siswa diharapkan mampu menemukan konsep sehingga konsep tersebut akan lebih melekat dalam struktur kognitif siswa. Agar siswa benar-benar bisa memahami materi dan praktek dengan benar, maka siswa perlu diberikan suatu situasi atau kondisi belajar yang kondusif, relevan dengan kehidupan nyata dan terstruktur.

Perbaikan tindakan pada siklus I memperbaiki pembelajaran pada siklus II, sehingga diperoleh peningkatan aktivitas belajar siswa pada siklus II diperoleh sebesar 14.77 dengan kualifikasi sangat aktif . Berdasarkan kriteria keberhasilan suatu penelitian dikatakan berhasil apabila mencapai kualifikasi aktif sedangkan untuk aktivitas siklus II sudah mencapai sangat aktif - Dengan, demikian pelaksanaan tindakan aktivitas belajar pada siklus II sudah bisa dikatakan berhasil. Sedangkan hasil belajar siswa baik rata-rata kelas, maupun ketuntasan klasikal. Nilai rata-rata hasil belajar siswa pada siklus II diperoleh sebesar 85.76 dengan kualifikasi memenuhi KKM dan dengan ketuntasan klasikal sebesar 92.31\% dengan kualifikasi memenuhi KKM. Berdasarkan kriteria keberhasilan, suatu penelitian dikatakan berhasil apabila kualifikasi nilai ketuntasan klasikal minimal $\geq 85 \%$. Dengan demikian, pelaksanaan tindakan pada siklus II sudah bisa dikatakan berhasil.

Hasil analisis data respon siswa terhadap model pembelajaran Kooperatif Tipe TAI pada mata pelajaran pengolahan dan penyajian makanan kontinental materi pokok pasta berbantuan Lembar Kerja Siswa (LKS) di SMK N 2 Singaraja ini rata-rata sebesar 80.29 dengan kualifikasi positif.

Berdasarkan hasil yang diperoleh, secara umum penelitian ini mampu meningkatkan aktivitas dan hasil belajar serta memproleh respon positif dari siswa terhadap model pembelajaran kooperatif tipe TAI berbantuan Lembar Kerja Siswa (LKS) di SMK N 2 Singaraja. Hasil penelitian menunjukkan bahwa PTK dengan metode Kooperatif tipe TAI cukup berhasil meningkatkan aktivitas dan hasil belajar siswa.

\section{PENUTUP}

\section{Simpulan}

Berdasarkan hasil penelitian tindakan kelas yang telah dilakukan dengan menggunakan model Kooperatif Tipe TAI pada mata pelajaran Pengolahan dan Penyajian Makanan Kontinental berbantuan Lembar Kerja Siswa (LKS), maka dapat ditarik kesimpulan sebagai berikut:

1. Model Kooperatif tipe TAI dapat peningkatkan aktivitas belajar siswa pada mata Pelajaran Pengolahan dan Penyajian Makanan Kontinental di kelas XIA5 dapat meningkatkan aktivitas belajar siswa yaitu dari rata-rata 10.28 siklus I menjadi 14.77 pada siklus II kualifikasi sangat aktif.

2. Model Kooperatif tipe TAI dapat peningkatkan hasil belajar siswa pada mata Pengolahan dan Penyajian Makanan Kontinental di kelas XIA5 dapat meningkatkan hasil belajar siswa yaitu dari rata-rata 79.67 siklus I menjadi 85.76 pada siklus II dengan kualifikasi tuntas.

3. Respon Siswa terhadap model kooperatif tipe TAI dapat meningkatkan hasil belajar siswa pada mata pelajran Pengolahan dan Penyajian Makanan Kontinental di kelas XIA5 berbantuan LKS di SMK N 2 Singaraja, dengan ratarata skor 80.29 yang berada pada kualifikasi positif

\section{Saran}

Mengacu kepada hasil temuan penelitian ini, dapat dikemukakan beberapa saran sebagai berikut:

1) Bagi siswa, agar selalu aktif dalam pembelajaran kooperatif tipe TAI berbantuan LKS untuk melatih dan meningkatan hasil belajar baik dalam kelompok untuk membantu memecahkan permasalahan belajar teman maupun permasalahan belajar individu.

2) Bagi guru produktif khususnya guru tata boga disarankan agar mencoba menerapkan model kooperatif tipe TAI berbantuan Lembar Kerja Siswa (LKS) dalam Mata Pelajaran Pengolahan dan Penyajian Makanan Kontinental sebagai 
alternatif untuk meningkatkan hasil belajar siswa.

3) Bagi sekolah diharapkan penelitian ini dapat dijadikan sebagai pedoman dalam pelaksanaan pembelajaran di sekolah tersebut khususnya pada model kooperatif tipe TAI berbantuan Lembar Kerja Siswa (LKS) untuk meningkatkan hasil belajar siswa yang optimal.

4) Bagi calon peneliti lain, agar menjadikan hasil penelitian ini sebagai bahan refrensi untuk melakukan penelitian lebih lanjut mengenai model kooperatif tipe TAI berbantuan Lembar Kerja Siswa (LKS) sehingga diperoleh hasil yang lebih maksimal.

\section{DAFTAR PUSTAKA}

Agung, A. A. Gede. 2011. Metodologi Penelitian Pendidikan. Singaraja: Fakultas Ilmu Pendidikan Universitas Pendidikan Ganesha..

Arikunto, S. 2011. Prosedur Penelitian Suatu Pendekatan Praktik. Jakarta: Rineka Cipta.

Dasripin, Ipin. 2008. Penggunaan Model Kooperatif Skrip dalam Pembelajaran. Menulis Narasi di Kelas VII SMPNegeri 1 Cigalontang Kab. Bandung. Tesis. Magister pada PPS UPI Bandung: tidak diterbitkan.

Depdiknas. 2008. Kamus Besar Bahasa Indonesia. Gramedia Pustaka. Indonesia.

E.Mulyasa. 2007. Standar Kompetensi dan Sertifikasi Guru. Bandung: PT. Remaja. Rosdakarya

M, R. (2013). Meningkatkan Self-Efficacy Pada Pembelajaran Matematika Melalui Model Kooperatif Tipe Team Assisted Individualization (TAI) Pada Siswa Kelas Viiasmp Negeri 27 Makassar. Jurnal Matematika Dan Pembelajaran (Mapan), 112.
Nurzakiaty, Ida. 2015. Penerapan Model Pembelajaran Kooperatif Tipe Team Assisted Individualization (TAI) Dalam Pembelajaran Integral Di Kelas XII IPA-2 SMA Negeri 8 Banda Aceh. Jurnal Peluang, Volume 3, Nomor 2.

Puspitasari, Luki. 2015. Penerapan Model Kooperatif Tipe Team Assisted Individualization (TAI) DALAM Peningkatan Pembelajaran IPA Di Kelas V. Kalam Cendekia, Volume 4, Nomor 2.

Ramlan, M. 2013. Meningkatkan SelfEfficacy Pada Pembelajaran Matematika Melalui Model Kooperatif Tipe Team Assisted Individualization (TAI) Pada Siswa Kelas VIIA SMP Negeri 27 Makassar. Jurnal Matematika Dan Pembelajaran (MAPAN), VOL. 1 NO. 1.

Sharan, S. (2012). Cooperative Learning. Yogyakarta: Familia.

Tarim, K., \& Akdeniz, F. (2007). The effects of cooperative learning on Turkish elementary students' Jurnal Ilmiah Sekolah Dasar, Vol. 2, No. 4, Tahun 2018, pp. 412-419419

Rizky, Ratna Wijayanti.2015 "Penerapan Model Pembelajaran Cooperative Tipe TAI (Team Assisted Individualization) Untuk Meningkatkan Belajar Dan Kemampuan Berpikir Kritis Matematika (mathematics achievement and attitude towards mathematics using TAI and STAD methods). Edu Stud Math .

Tinungki, G. M. (2015). The Role of Cooperative Learning Type Team Assisted Individualization to Improve the Students' Mathematics Communication Ability in the Subject of Probability Theory. IISTE .

Ujiati, Cahyaningsih. 2018. Penerapan Model Pembelajaran Kooperatif Tipe TAI 
(Team Assisted Individualization)

Untuk Meningkatkan Hasil Belajar

Siswa Pada Mata Pelajaran Matematika.

Jurnal Cakrawala Pendas Vol. 4 No.1 